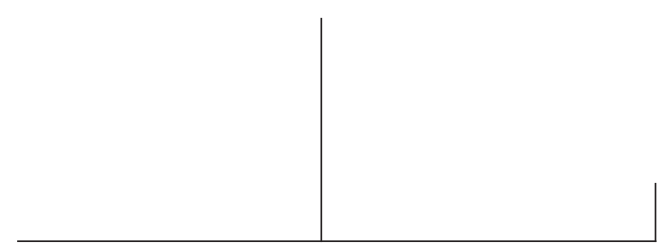

Rev. Latinoam. Psicopat. Fund., II, 2, 11-36

\title{
A drugstore de Platão (os psicofármacos)
}

\author{
Rubens Coura
}

A partir do livro A farmácia de Platão, de Jacques Derrida, é rastreada, nos próprios textos platônicos, a admiração daquele filósofo grego pela então incipiente medicina hipocrática: ela se harmonizava com o método dialético de Platão, em oposição à estreiteza do método sofista, que se compunha melhor com a medicina pré-hipocrática dos charlatães curandeiros.

Chega-se ao phármakon hipocrático, com suas primitivas e atuais propriedades de Droga, de Tintura, de Escritura e de Objeto Numinoso. E na atual Drugstore, que veio usurpar o tradicional espaço da farmácia, $o$ phármakon ainda vem se mantendo como tal e não se esvazia na categoria inerte de um simples product; mas isso ocorre apenas através dos esforços da propaganda maciça, de exorbitâncias da pesquisa científica e da precariedade da maioria dos atendimentos médicos da atualidade.

Também na psicofarmacologia, são muitas as modificações (patoplásticas) geradas pelas mutilações contemporâneas sofridas pelo phármakon; entre elas, o autor destaca que os phármakons antidepressivos podem propiciar, no reequilíbrio pulsional que favorecem, apenas uma espécie de "adiamento" da destruição e do triunfo sobre o objeto perdido no melancólico - não parecendo influir, apesar da aparente melhora no quadro clínico, na força sádica destrutiva do sujeito.

Palavras-chave: Psicopatologia, psiquiatria, psicofármacos, pharmakon. 


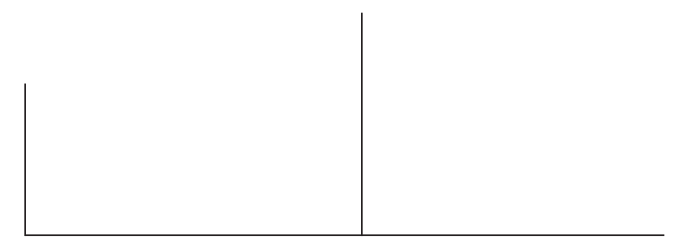

Nesse título, onde a tão prosaica e anônima drugstore substitui a respeitável farmácia, numa alusão direta ao livro A farmácia de Platão, de Jacques Derrida, devo me apressar na justificativa de que o sentido óbvio de ironia não contém qualquer mordacidade contra a notável obra desse pensador francês, nem muito menos - como poderia? - contra o inventor do pensamento racional no Ocidente. A melancólica substituição das duas palavras, ambas referentes a um estabelecimento onde hoje se pode adquirir um phármakon, procede de um profundo desagrado meu quanto à verdadeira deterioração pela qual esse mesmo phármakon (especialmente o psicofármaco) pode ser degradado nos seus usos contemporâneos chegando a ser utilizado para pulverizar a psicopatologia em meras queixas esparsas. Mesmo quando ele ainda esteja dentro do prazo de validade que vem impresso na caixinha...

No próprio Fedro (270b), estudado por Derrida nesse seu livro, Platão faz Sócrates dizer que a ciência médica tem o mesmo caráter que a retórica, no sentido de ambas analisarem uma natureza: a do corpo e a da alma, respectivamente. Nas técnicas de ambas, a ciência médica administraria ao corpo medicamentos e alimentos promovendo desta forma a saúde e a força; a dialética, visando a alma, proporcionaria idéias e ocupações justas que pudessem conduzir à convicção e à virtude. ${ }^{1}$

1. Platão. "Fedro, o de la belleza" (270b). (Trad. de Maria Araújo). In Obras Completas, Madrid, Aguilar, 1974, p. 878. 


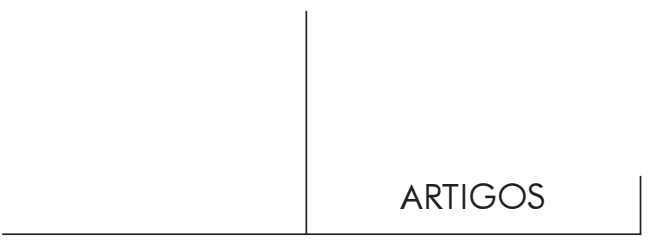

Segundo Werner Jaeger, Platão - que desde o início de seu pensamento teria se ligado à Medicina hipocrática - focaliza aqui a concepção orgânica da natureza, na qual a Medicina hipocrática lhe serviria de modelo no método de investigação pelo qual se busca compreender, antes de mais nada, a função da parte no todo para, assim, depois se determinar o que seria mais adequado ao tratamento dessa parte que é a alma. ${ }^{2}$

Sabemos que a medicina, então, ainda compunha um muito jovem conhecimento humano - e que os homens cultos em geral a estudavam em seus princípios básicos, derivados da filosofia jônica da natureza: para diversos filósofos e ao longo de quase dois séculos (VI a IV aC.), a noção de physis está na origem desse pensamento antigo: aquilo que é o que é por natureza, independentemente da decisão ou vontade racionais dos homens. ${ }^{3}$ Era como um significativo desenvolvimento desse fértil ramo da compreensão do mundo que a medicina dos hipocráticos interessava os pensadores gregos como Platão.

Com efeito, ainda no Fedro (270b/270c) lemos que a compreensão da natureza da alma exige o método da compreensão prévia da natureza do todo; e que sem tal método (ele menciona diretamente Hipócrates) não se poderia entender sequer a natureza do corpo:

Sócrates: - A ciência médica tem, de certo modo, o mesmo caráter da retórica. Fedro: - Como assim?

Sócrates: —Em ambas é preciso analisar uma natureza: a do corpo em uma, a da alma na outra, se se quer recorrer não somente a uma rotina e a uma prática, mas a uma técnica, para ministrar ao corpo remédios e alimentos e produzir assim, nele, a saúde e a força; e para a alma, idéias e ocupações justas para lhe transmitir a convicção e a virtude que são desejáveis.

Fedro: - Ao menos, Sócrates, é verossímil que assim seja.

Sócrates: - E a natureza da alma, crês que é possível compreendê-la dignamente sem a natureza do todo?

Fedro: - A acreditarmos em Hipócrates, o discípulo de Asclepíades, nem sequer a do corpo pode ser entendida se não se seguir esse método.

Sócrates: - Sem dúvida, amigo, tens razão. Contudo, temos de examinar, à parte de Hipócrates, a razão, para ver se ela está de acordo com ele. ${ }^{4}$

2. Werner Jaeger. Paidéia: a formação do homem grego. (Trad. de Artur M. Parreira). São Paulo, Martins Fontes, 1986, p. 709.

3. Marilena Chauí. Introdução à história da filosofia: dos pré-socráticos a Aristóteles, vol. I. São Paulo, Brasiliense, 1994, p. 354.

4. Platão, "Fedro, o de la bellezza" (270b/270c). Op. cit., p. 879. 


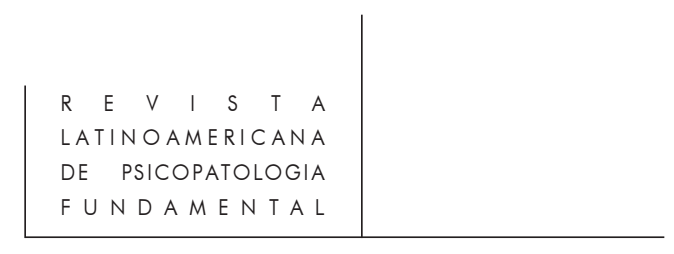

Antes do Fedro, Platão situa um jovem Hipócrates, aspirante à carreira médica, como um dos personagens do seu Protágoras (313a /313c); é um dos amigos de Sócrates que vai participar do debate com o sofista que chegara a Atenas. Tentando convencer Hipócrates a não confiar sua alma a um sofista como Protágoras (por serem os sofistas opositores da dialética), Platão põe argumentos na boca de Sócrates para dizer ao jovem:

- Acaso um sofista, Hipócrates, não vem a ser um comerciante ou um mascate que vende os gêneros de que se nutre a alma? A mim, ao menos, parece que é assim.

- Mas o que vem a ser esse alimento da alma, Sócrates?

- Sem dúvida são as diversas ciências... E não vamos nos deixar enganar, meu amigo, pelos elogios que o sofista faça sobre o que ele vende, como tampouco deixamos que o façam os mercadores... Esses nos trazem seus gêneros sem saberem, eles próprios, se são bons ou maus para a saúde, mas os fazem valer todos indistintamente e o comprador não sabe mais que eles sobre isso, a não ser que seja educador ou médico. Da mesma forma, os que vão vendendo seu saber de cidade em cidade, para vendê-lo no todo ou em parte, elogiam tudo o que oferecem para seus clientes, sem sequer saberem eles próprios quais coisas são boas para a alma e quais são más; e o cliente não sabe disso mais do que eles, a não ser que haja estudado a medicina da alma... ${ }^{5}$

Mas posterior ao Fedro e um dos textos de Platão que talvez mais nos auxiliem, no estrito sentido do que aqui tratamos, seja o "As leis" (720b/720e) obra considerada de sua última maturidade; nele, um ancião de Atenas expõe a um ancião de Creta a necessidade da pólis de contar com legisladores que elaborem as leis visando não somente a punição, mas, sobretudo, a educação virtuosa dos cidadãos. Platão emprega uma comparação dos dois tipos de legislação, a punitiva e a educativa, com o que ele chama de duas categorias de médicos: os de uma medicina empírica e rude empregada por médicos escravos e os de uma medicina verdadeiramente hipocrática praticada pelos homens livres. Referindo-se aos aprendizes de medicina, diz ele, pela boca do ateniense:

- Estes podem ser livres ou escravos; neste último caso se formam segundo as instruções de seu dono, vendo-o exercer e de uma maneira empírica, não aprendendo a ciência da natureza que os homens livres adquirem por si mesmos e depois ensinam a seus discípulos...

Ele continua, após a anuência do ancião cretense a suas ponderações:

5. Platão. "Protagoras, o los sofistas" (313a /313c). (Trad. de Francisco de P. Samaranch). In Obras Completas, op. cit., p. 163. 


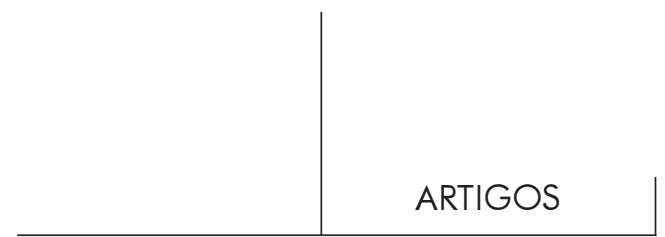

- Posto que existem nas cidades, entre os doentes, os que são livres e aqueles que são escravos, imagino que, comumente, são os escravos que cuidarão de seus semelhantes ... nenhum desses médicos dá nem aceita explicação alguma sobre os casos individuais dos diferentes servos, mas prescreve o que o empirismo lhe sugere, como se estivesse perfeitamente informado, adotando a pose de um tirano e assim vai, com grande rapidez, atender o próximo escravo doente... O médico livre, por outro lado, cuida e examina, como coisa comum, as doenças das pessoas livres; estuda a doença desde seu início e segundo seus fundamentos naturais, troca impressões com o próprio doente e com os amigos e agregados dele e, ao mesmo tempo em que ele pessoalmente aprende junto aos enfermos, vai instruindo o mesmo paciente, à medida que isso lhe é possível, sem nada prescrever-lhe até que tenha conseguido convencê-lo da necessidade disso; e então, ajudado pela persuasão, tranqüiliza e prepara continuamente o seu doente, até conseguir levá-lo pouco a pouco à saúde. ${ }^{6}$

Não estranhemos a presença de escravos exercendo medicina na Antiguidade grega; era grande a heterogeneidade das ocupações desses homens desprovidos de liberdade e eles também praticavam o ofício de médico na Roma Antiga, como nos é confirmado, entre outros, pelo historiador Yvon Thébert. ${ }^{7}$

É impossível não reconhecer, nessas ponderações que Platão nos faz sobre os dois tipos de médicos, a notável semelhança da conduta do médico escravo grego com aquela a que se vê forçada considerável parte de nossos esculápios atuais: a falta de argumentações de parte a parte com o paciente, a extrema rapidez do atendimento ao se passar de um doente para o próximo, a pose "tirânica" que visa conferir uma respeitabilidade momentânea. E ainda a subordinação do médico a uma autoridade que lhe é muitíssimo superior. É o seu amo, no caso do médico escravo Grego, ou até uma entidade gerenciadora, no caso de muitos médicos contemporâneos (e que pode ser configurada por algumas formas de seguro-saúde ou por determinadas instituições governamentais ou hospitalares). Voltaremos a esse ponto na questão do phármakon nos dias atuais, como Objeto Numinoso.

Werner Jaeger reitera a estreita ligação do pensamento de Platão com a medicina hipocrática, ressaltando que a concepção platônica das virtudes éticas da alma deriva da sua noção das "virtudes" do corpo: a simetria das partes ou das forças naturais, ou seja, o estado considerado como normal - na medicina grega ${ }^{8}$. Portanto, o phármakon platônico não deve ser compreendido como toda e qualquer

6. Platão. "Las leyes, o de la legislacion" (720b/720e). (Trad. de Francisco de P. Samaranch). In Obras Completas, op. cit., pp. 1342-1343.

7. Yvon Thébert. "The Slave". In Giardina, Andrea (Ed.). The Romans. (Translated by Lydia G Cochrane). Chicago, University of Chicago Press, 1993, pp. 138-174.

8. Idem, p. 710. 


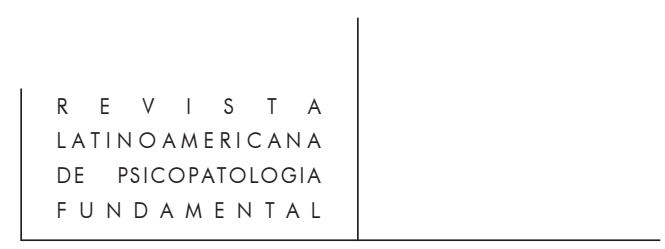

intenção curativa do emprego de medicamentos, remédios ou medicinas para o que hoje consideramos como tratamento de algum doente - prática universal e antiquíssima entre os povos do mundo inteiro. Na eventualidade de poderem existir outros tipos de phármakon, com outras propriedades diversas dessas, é importante não perder de vista que é especificamente do phármakon hipocrático que Platão nos fala.

Tomo emprestada a nomenclatura adotada por Jorge J. Saurî para as quatro possíveis acepções de phármakon, quando ele se debruça sobre o estudo da terapêutica psiquiátrica, também sob os mesmos ecos platônicos. Utilizo algumas de suas definições, todas carregadas da ambigüidade ou ambivalência próprias do phármakon, acrescidas das correspondências que faço com a medicina hipocrática:

1) Como Droga - pode ser remédio e/ou veneno. No sentido hipocrático, pode-se compreender aqui o medicamento em suas quantidades benéficas ou prejudiciais (segundo cada paciente e cada período da moléstia). Mais apropriadamente, o medicamento naquilo que ele tem de uma fronteira variável entre acarretar a melhora ou a intoxicação: nos antidepressivos atuais, o limite entre a melhora do quadro melancólico/depressivo e a chamada "virada maníaca" que pode ser induzida pelo próprio psicofármaco que se emprega para debelar o estado melancólico ou depressivo.

2) Como Tintura - pode fazer algo parecer outra coisa: uma substância modificadora do natural, introdutora de características suplementares. Hipocraticamente, pode compreender os tratamentos meramente sintomáticos, que não abrangem as causas da doença: como um antitérmico que pode baixar a febre, mas que não combate a infecção que está desencadeando essa febre.

3) Como Escritura - favorece a recordação e incita o esquecimento: pela confiança no que já está escrito, ocorre o descuido no cultivo da memória. No sentido hipocrático, pensamos na descrição escrita do emprego dos tratamentos médicos: a inflexibilidade ou rigidez do escrito, quando da aplicação dos medicamentos (comum nas fórmulas e ritos mágicos das medicinas anteriores e daquelas contemporâneas dos hipocráticos), parece ter preocupado os discípulos da Escola de Cós. Assim, sobre as dietas dos doentes, podemos perceber a atenção com as singularidades de cada paciente:

Se fosse simplesmente, como se pensa, que tudo o que é demasiado forte prejudica e tudo o que é leve beneficia e nutre tanto o doente como o sadio, as coisas seriam relativamente fáceis; adotando uma ampla margem de segurança, bastaria tender ao mais suave. (...) Muitos males, diferentes porém não menos terríveis que

9. Jorge J. Saurí. “Tenor de la terapéutica". Revista Latinoamericana de Psicopatologia Fundamental, vol. I, no 1, São Paulo, 1998, pp. 19-22. 


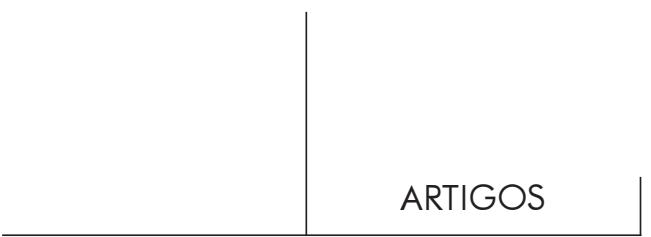

os causados pelo excesso de alimentação, procedem igualmente do jejum. Por isso, o assunto é muito mais complexo e requer maior precisão, pois há que definir uma certa medida. E a única medida, número ou peso válido a que se poderá recorrer, para se reconhecer o que é o adequado, vem a ser a percepção sensível do corpo humano. ${ }^{10}$ (grifos meus)

4) Como Objeto Numinoso - remete ao mágico, numa função expiatória. Em termos de uma medicina hipocrática, penso que se possa aqui situar a expectativa mágica de cura que fica investida, pelo doente, na imagem do médico que dele cuida; é isso que (creio que indevidamente) se costuma chamar de "a transferência" do doente sobre o seu médico.

O que de função expiatória deve aí existir consiste, certamente, na mobilização inconsciente de forças auto-punitivas ligadas às representações psíquicas mais próximas dos sentidos da sua doença, para o próprio enfermo. Dessa forma, por exemplo, em paciente medicado com antidepressivos - e desde que ele efetivamente esteja melancólico/deprimido - podemos perceber a tendência dele de sofrer muito com efeitos colaterais da droga e, concomitantemente, referir-se a tais efeitos como de alguma forma necessários ou como "bons sinais" de sua melhora clínica.

O próprio sabor desagradável de muitos remédios é, tradicionalmente, considerado como parte importante e benfazeja do tratamento, mais visível por parte de pessoas menos cultas:

- O remédio bom é sempre amargo..! - ouvimo-los dizerem, não obstante a atual tendência dominante a fazê-los (pelo efeito de Tintura) com os mais palatáveis sabores de morango ou de chocolate.

A noção de Objeto Numinoso, na medicina hipocrática, está contida também nessa pequena obra do Corpus Hippocraticum que é a Lei (Nómos) - provavelmente destinada aos jovens candidatos à carreira médica da antiga Atenas - a qual reza em seu último parágrafo:

As coisas que são sagradas devem ser reveladas aos homens sagrados; aos profanos, elas não são permitidas enquanto eles não sejam iniciados nos mistérios da ciência. ${ }^{11}$

Situadas dessa forma as quatro possibilidades do phármakon, torna-se imperioso não nos esquecermos de que boa parte da prática médica contemporânea vem se desenvolvendo sob o patrocínio de uma ideologia da produtividade - de

10. Hipócrates. "Sobre la medicina antigua" (Trad. de Maria Dolores Lara Nava). In Tratados hipocráticos, vol. I. Madrid, Gredos, 1983, pp. 145-146.

11. Hipócrates. "Ley" (Trad. de Maria Dolores Lara Nava). In Tratados Hipocráticos, op. cit., p. 94. 


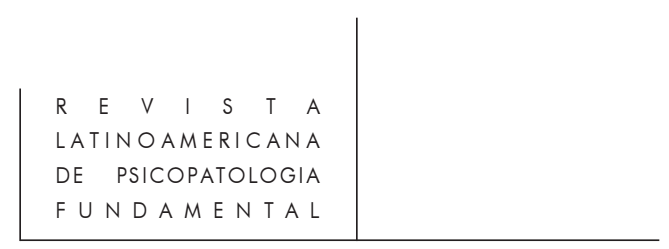

uma gigantesca e anônima escalada mundial pela produtividade, que abrange a necessidade de corpos cada vez mais saudáveis; nessa empresa tecnológica universal, o médico desempenha, na verdade, um papel muito restrito, embora seja chamado a prestar contas dessa Saúde sem limites - como alertou Lacan (1966) para os membros do Colégio de Medicina, em Paris. ${ }^{12}$

Num outro texto meu, considerei que estamos atravessando uma era obsessiva - não melancólica nem depressiva, como pode fazer crer o atual furor pelos phármakons antidepressivos; em tal situação, repetem-se coletivamente as características da neurose obsessiva, com seus mecanismos de deslocamento do afeto, anulação retroativa e isolamento - com a especialmente nítida presença de rituais esconjuratórios e escrúpulos de feitio religioso.

Tal era obsessiva está subordinada a uma identificação mútua das pessoas baseada no fervoroso empenho grupal por uma saúde que seja plena e que confira nada menos que a imortalidade do corpo. ${ }^{13}$

Essa tonalidade psíquica coletiva inclui o esvaziamento da tradicional função médica hipocrática de cuidar bem dos doentes e de procurar ajudá-los a sararem de seus males - pois tal disposição é demasiadamente modesta diante das garantias de imortalidade do corpo que estão sendo hipotecadas ao crédito da ciência contemporânea. Dentro dela, o médico vai cada vez mais se apoucando como a menor e última engrenagem de uma fantástica maquinaria científica.

E o phármakon, como fica ele sob os vapores e miasmas dessas novas dimensões com que se vem dilatando uma elefantíase da ciência ocidental cristã? Teria sido ele despojado das quatro características que o definem para se tornar uma outra e estranha coisa, ainda sem nome?

À primeira vista, isso que é vendido nas drogarias e farmácias, parece muito distante de quaisquer acepções do phármakon platônico; como praticamente independe do pensamento médico sobre suas indicações mais precisas e sobre suas contra-indicações a médio e longo prazos, assemelha-se grandemente aos produtos fornecidos pelo estabelecimento - quase tão distantes de qualquer rigor médico quanto as tinturas para cabelo ou os perfumes que são oferecidos ao público nesse mesmo estabelecimento. Tal local não se configura bem como drogaria ou farmácia, mas muito melhor como drugstore: um farto e variado mercado de produtos relativos a tratamentos de saúde, à alimentação, à beleza e à higiene e que são colocados ao alcance de qualquer freguês. O dicionário de inglês define um local assim (nos

12. Jacques Lacan (1966). "Psicoanálisis y medicina". In Intervenciones y textos, vol. I (Trad. de Diana Silvia Rabinovich). Buenos Aires, Manantial, 1985, pp. 86-99.

13. Rubens Coura. "Quando os psicofármacos fazem confundir melancolia e depressão". Revista Latinoamericana de Psicopatologia Fundamental, vol. I, no 2, São Paulo, 1998, pp. 9-22. 


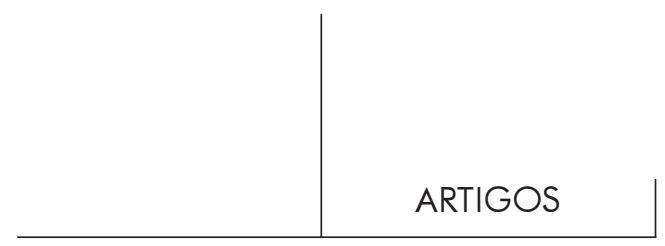

Estados Unidos) como drugstore: “...lugar onde uma grande variedade de artigos é vendida, onde receitas médicas podem ser atendidas e onde comida e bebida podem ser compradas e consumidas." 14

Dentro da concepção de drugstore, tal medicamento parece se revestir muito mais com características de product (produto) do que de phármakon: o nome product assim mesmo, em inglês da América do Norte, pois é de lá que procede essa noção de drugstore, com seus múltiplos produtos comerciais ao alcance das mãos.

Repassemos as quatro características (ou possibilidades) do phármakon, agora já plenamente dentro dessa era obsessiva que duramente estamos palmilhando, na tentativa de verificar se ele ainda consegue guardar as características que há tantos séculos vêm justificando sua realidade como phármakon platônico:

1) Como Droga - ainda pode ser remédio ou veneno, mas com a balança pesando muito mais para a possibilidade do remédio muito perigoso ou veneno; não mais provindo das mãos do médico, raramente elaborado em receitas para manipulação e muitas vezes já conhecido do paciente pelos efeitos colaterais (através da imprensa falada e escrita), o medicamento tende a produzir na pessoa um efeito de desconfiança: ele provém de fontes remotas e a drugstore é geralmente percebida pelo paciente como apenas uma espécie de entreposto ou de ponto comercial de revenda.

Essa desconfiança exacerbada dos pacientes aparece mais freqüentemente na forma deles indagarem sobre os riscos do uso do produto (até ao simples balconista da farmácia) antes mesmo de perguntarem sobre seus possíveis benefícios; fazemno assim também ao médico que prescreve o medicamento, quando têm oportunidade e tempo de fazê-lo durante uma rapidíssima consulta. Mas essa desconfiança é talvez mais nítida ainda nas manifestações de psicologia coletiva, como nas recorrentes notícias de graves efeitos colaterais (e mesmo de mortes) pela imprensa; deve ser também esse efeito de veneno que faz emergirem as notícias sobre medicamentos falsificados, sobre elevação excessiva ou ilegal do preço dos remédios, sobre indenizações exigidas de laboratórios farmacêuticos etc.

Mais específica dos psicofármacos, inclusive dos antidepressivos, é a preocupação com o risco de "criar dependência" do medicamento. A desconfiança contra eles aparece também na forma de medo de efeitos teratogênicos sobre o feto - inclusive, como presenciei, em mulheres histerectomizadas ou menopausadas! Percebe-se a verbalização de temores travestidos de palavras obtidas do vocabulário

14. A.S. Hornby. Oxford Advanced Learner's Dictiornary of Current English. London, Oxford University Press, 1974, p. 272. 


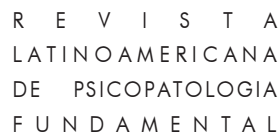

científico pertinente à questão, porém sem qualquer relação mais verdadeira com o caso clínico pessoal.

Outro possível efeito do phármakon (no caso dos antidepressivos) como Droga-veneno se entrelaça com o seu efeito de Tintura como disfarce ou simulacro: para que a melhora de um paciente melancólico/depressivo seja considerada satisfatória, não se espera que ele retorne, necessariamente, às suas disposições psíquicas básicas anteriores à instalação do quadro doentio. Basta que ele se sinta menos triste, mais disposto, mais produtivo, mais contente; e isso pode ocorrer pelo efeito de Droga-remédio que se busca no phármakon, para o seu caso - mas não significa, em absoluto, que só se considere tal paciente como beneficiado pelo tratamento se ele "voltar a ser o que era" antes do advento do episódio depressivo. De fato, não são poucos os pacientes assim tratados que estranhem seu estado de melhora:

-É, Doutor, eu me sinto contente por estar livre daquela depressão horrorosa, mas... eu nunca fui desse jeito de agora! - pode referir o paciente em sua melhora clínica.

Outras vezes, são os familiares do paciente que confidenciam ao médico:

- Ah, nem se compara esse estado atual dela com aquele da depressão (não quero nem lembrar!); mas, Dr., ela não é mais a mesma de antes: parece meio distante da gente, não se interessa mais por um monte de coisas..!

2) Como Tintura - o poder fazer algo parecer uma outra coisa ou modificar o natural, também parece exacerbado nas atuais circunstâncias de uso de medicamentos; o parecer mais jovem e sexualmente apto, que sempre foi uma grande aspiração humana, adquire aqui um sentido de obrigatoriedade e de negação da maturidade como etapa da vida e como possibilidade de sabedoria: o Ideal do Ego clama por eficácia e juventude - assimiladas à força muscular, à rapidez e à menor reflexão, que costumam ser atributos dos jovens.

Mas o que é mascarado ou maquiado para parecer ser o que não é? Podemos supor que ocorra o mecanismo de se poder mascarar sintomaticamente o quadro depressivo/melancólico de um paciente, através da administração de um phármakon antidepressivo (sem que se busque o funcionamento inconsciente desse processo melancólico no paciente); no entanto, tal modificação do natural pelo efeito de Tintura se confunde com o próprio efeito de Droga como remédio pelo mesmo phármakon. Creio que somente a eventual intensidade dos efeitos colaterais ou de toxicidade, os efeitos da Droga como veneno para esse paciente, é que poderão levar a se abrir mão de seu emprego - dentro do próprio critério hipocrático de se buscar reequilibrar o natural para esse doente.

$\mathrm{O}$ aspecto do tratamento com phármakons antidepressivos que pode se revestir com forte efeito de Tintura, de máscara ou simulacro, reside no seu emprego com uma eventual aliança com critérios diagnósticos que contrariam os princípios 


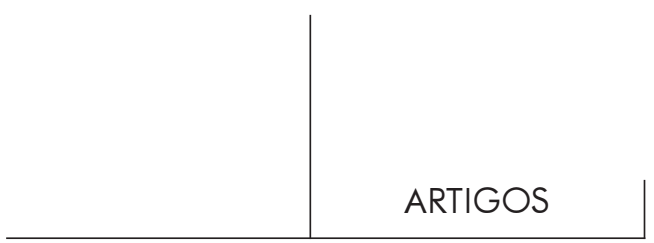

hipocráticos: é o caso da busca de um comportamento standard, de uma alegria plastificada de pessoas que procuram o médico sem que estejam doentes: procuram em drogas uma máscara para a alma, no dizer de Moacyr Scliar ${ }^{15}$. E fazem-no, ainda de acordo com esse escritor e médico, porque a nossa época vê na melancolia uma ameaça à inserção social do indivíduo, à sua capacidade produtiva.

Outra e certamente mais séria busca do phármakon pelo seu efeito de simulacro como Tintura, aparece nessa cornucópia da abundância de empregos dos medicamentos antidepressivos; não gostaria de abordar aqui a questão dos recentes e tão discutíveis diagnósticos psiquiátricos onde essa classe de medicamentos também encontra emprego - como a assim chamada síndrome do pânico, por exemplo. Mais sinuosas e sutis me parecem as situações onde o efeito de Tintura do phármakon é buscado para mascarar mais prolongadamente, como um simulacro que ludibria mais pessoas e por mais tempo que o eventual engano com alguns novos diagnósticos - que se arriscam a apenas rebatizar velhos e conhecidos sintomas isolados.

Maior eficácia em termos de simulação e máscara não pode deixar de evocar a histeria, banida dos critérios diagnósticos considerados em muitos meios científicos como os mais exatos: os da American Psychiatric Association, reunidos no seu Manual Diagnóstico e Estatístico de número IV, de sigla DSM-IV. Tais critérios advêm da "escola de St. Louis", da psiquiatria universitária norte-americana, sendo que "...o modelo desta clínica tem por base a resposta-padrão à administração de uma substância química específica” - como nos esclarece Márcio Peter de Souza Leite ${ }^{16}$.

Dentro desses novos critérios, a histeria foi substituída por um "distúrbio dissociativo" e a sua forma conversiva, de maneira incompreensível, foi dela isolada e posta junto aos assim chamados "transtornos somatoformes".

Mas como evidentemente a histeria não deixou de existir por efeito dessa pirueta diagnóstica, os pacientes histéricos continuam procurando ajuda - inclusive ajuda médica. E continuam com seu faro infalível para tudo o que obrigue a atenção dos médicos, no momento; como os holofotes da expectativa e da valorização científicas se voltam agora para os psicofármacos antidepressivos, é preferencialmente ao redor desses phármakons que eles rearranjam sua neurose.

Como se sabe, as pacientes histéricas acorriam ao palco de Charcot, seduzindo-o na forma de se deixarem hipnotizar por ele e com o testemunho de uma Paris excitadíssima na platéia: era o orgulho científico desse médico e o seu

15. Moacyr Scliar. "Editorial: 'Entrevista com Moacyr Scliar'”. Boletim de Novidades da Livraria Pulsional, Ano X, no 99, julho/1997, pp. 3-7.

16. Marcio Peter de Souza Leite. "Velhos sintomas, nova classificação: o DSM-IV e a psicanálise". Boletim de Novidades da Livraria Pulsional, Ano X, no 99, julho/1997, pp. 63-69. 


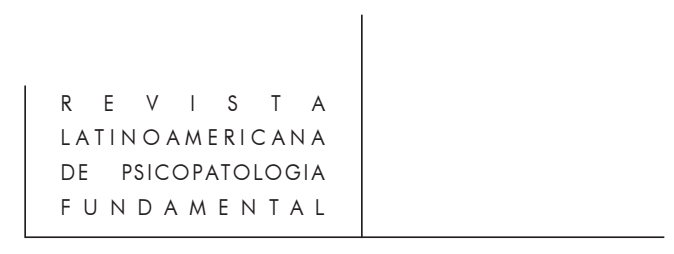

recurso técnico hipnótico que brilhavam na época. Analogamente, hoje, com o pólo desse interesse centrado no phármakon antidepressivo, muitas dessas mesmas pacientes chegam às consultas com queixas de feitio depressivo; com os sintomas de depressão exaustivamente catalogados pelos jornais, revistas leigas e pela TV e com anamneses inadvertidamente muitas vezes dirigidas para se apurar quadros depressivos - essas pacientes podem, com facilidade, receber o diagnóstico de "depressão" e serem medicadas com psicofármacos antidepressivos.

Mesmo antes do banimento da histeria da prestigiada classificação diagnóstica norte-americana, seu nome já provocava mal-disfarçados desprezos e incompreensões entre seus familiares e até de seus médicos. Com o agora respeitável diagnóstico de "depressão", tais pacientes podem obter o ganho secundário que lhes vinha sendo negado, inclusive em termos de dignidade para seu sofrimento psíquico. O desafio ao médico e o inevitável fracasso no seu empenho de cura vieram reencontrar o espaço até há pouco perdido nos hospitais, clínicas e consultórios. Em lugar do recurso, já finalmente gasto pelo uso, de telefonar para a residência do facultativo na madrugada para lhe dizer que o namorado a insultou gravemente - e que ela ingeriu de uma só vez todos os comprimidos que esse médico lhe prescreveu - hoje basta a essa paciente diagnosticada como deprimida the comunicar que está se sentindo subitamente muito alegre e muito excitada: essa insinuação ao profissional de uma possível "virada maníaca" pelo phármakon antidepressivo, receitado por ele próprio, pode perfeitamente exigir dele medidas ainda mais imediatas e angustiadas que aquelas mais antigas e já em descrédito, decorrentes de uma suposta ingestão excessiva de tranqüilizantes.

A histeria pode encontrar hoje, no efeito de Tintura do phármakon antidepressivo, o simulacro provavelmente mais eficaz de que dispõe desde que, no século XIX, extorquia do médico indicações de repouso em balneários estivais - após um grande ataque histérico.

O que estou aqui considerando como um atual e insuspeitado efeito de Tintura do phármakon, como simulacro, consiste na busca e na obtenção do diagnóstico de "depressão", por pacientes histéricos, através do uso (ou suposto uso) desse phármakon como Droga-remédio.

Uma outra situação médica, que como a anterior também tenho visto ocorrer junto a médicos psiquiatras (inclusive em momentos de supervisão ou orientação dos atendimentos realizados por eles junto a seus pacientes), bem como com outros especialistas prescrevendo psicofármacos, também pode exemplificar esse novo e subterrâneo efeito de Tintura como simulacro: ocorre no uso dos chamados estabilizadores do humor, com freqüência associados aos antidepressivos porque geralmente são prescritos visando evitar ou atenuar sintomas de depressão. Dentre esses, o mais efetivo parece ser o Carbonato de Lítio, cujo metabolismo no corpo humano exige cuidados especiais na verificação de sua toxicidade; as doses eficazes 


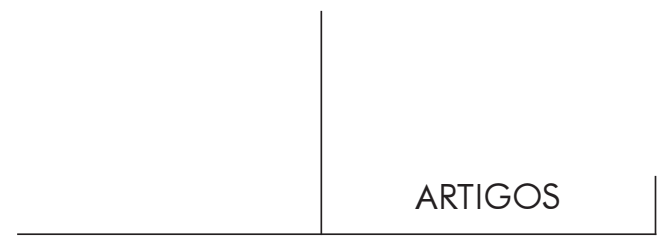

costumam estar bastante próximas das doses tóxicas (sendo que sua elevação demasiada na corrente sanguínea pode implicar até em risco de vida para o paciente): seu efeito de phármakon como Droga-remédio é sabidamente muito próximo do seu efeito como Droga-veneno.

Daí a necessidade de estrito controle dos seus níveis sanguíneos através de exames laboratoriais e de algumas restrições dietéticas, cuidados que são conhecidos pelos pacientes e que - para os que utillizam o medicamento há anos - já se tornou uma espécie de hábito. Acontece que muitos pacientes histéricos, diagnosticados como "deprimidos" (ou "distímicos", "bipolares" ou ainda com "transtorno depressivo do humor") - diagnóstico que geralmente lhes apraz muitíssimo mais do que os mais antigos de "histeria", "neurose" ou "ansiedade" - aceitam surpreendentemente bem as imposições do tratamento com um phármakon assim delicado. Mas é compreensível que inicialmente pareçam acolhê-lo bem, pois tal proposta terapêutica pode implicar num suposto desequilíbrio bioquímico nos neurotransmissores cerebrais (com uma possível carga genético-hereditária), geralmente explicado (ou subentendido) como tendo independência dos temores, motivações e desejos do paciente. Algo primariamente químico e que estaria na origem de seu sofrimento psíquico e que determinaria sua conduta em geral, à sua total revelia.

É claro que sair de uma consulta médica com tal diagnóstico, com tal receita e com tal explicação de mecanismos psíquicos acarreta muito mais tolerância (e muito mais sentimentos de culpa) dos familiares do que a postura médica anteriormente mais comum para esses casos:

- É, a Sra. tem uma angústia, um nervosismo muito forte... mas este calmantezinho vai ajudá-la a ficar mais tranqüila - diziam-lhes frequentemente os facultativos. Mas como chegar em casa retornando da consulta, diante de familiares já versados em calmantes e em crises nervosas, tendo nas mãos apenas mais uma "receitinha de calmante" - e nos ouvidos, o ocioso conselho para "não ficar nervosa"?

Esse era o mais comum dos impasses com pacientes histéricas nas consultas médicas, antes do advento dos novos phármakons antidepressivos e dos diagnósticos que tantas vezes são deles derivados.

No entanto, em se tratando de histeria, são o entusiasmo e o interesse do médico pelos efeitos desse phármakon estabilizador do humor que aguçam os ciúmes da paciente - que passa a desafiá-lo tão logo detecte essa cobiçada eficácia terapêutica; ela transforma a estreita faixa entre o efeito de Droga-remédio e o de Droga-veneno num vastíssimo espaço de manipulação desse médico, tomando os possíveis efeitos colaterais como armas contra a vitória terapêutica, tornada então a materialização de uma rival que lhe foi negada no plano psíquico inconsciente: como se rivalizaria ela com a impalpável e informe Dona Serotonina? 


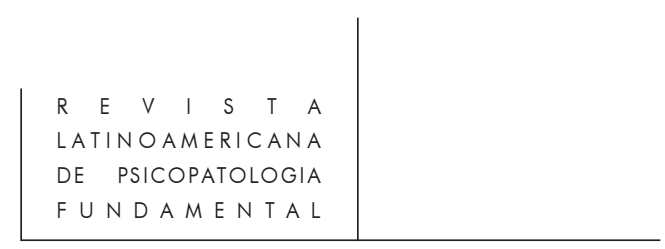

Como no foco das lentes das sofisticadas máquinas fotográficas do laboratório do Dr. Charcot, na Salpêtrière, também aqui se tenta apreender e paralisar o psíquico - através de exames de sangue que registrem os níveis da droga também no psiquismo. Mas, como nas poses para as máquinas do Dr. Charcot, também aqui os histéricos fazem de conta que estão encaixados na ciência; da mesma forma como aquelas fotos não implicavam nem na mais remota melhora clínica dos pacientes, tais empenhos de controle sanguíneo do phármakon também não traduzem, nesses casos, qualquer evolução confiável das possibilidades terapêuticas do estabilizador do humor: os níveis medidos no exame laboratorial se elevam e se abaixam em desacordo com a dose que deveria estar sendo ingerida, cria-se uma oscilação muito perigosa do limite entre o efeito-remédio e o efeito-veneno e o médico se vê na contingência de suspender o tratamento com esse phármakon. Até que isto ocorra, a paciente, seus famíliares e o médico já se mobilizaram muito ao redor dos tantos mistérios do metabolismo e das sempre possíveis reações inesperadas da bioquímica pessoal - via de regra, com um descontentamento que acusa o fracasso desse médico e aponta a direção da escolha de um outro, para prosseguir o tratamento da doente. Dispondo de uma grande lista de profissionais no "livrinho" dos credenciados pelo convênio médico, pode-se facilmente imaginar que vários deles serão os próximos a ingressar, inadvertidamente, no novo simulacro "depressivo" do antiquíssimo embuste clínico da histeria.

Finalmente, como efeito-Tintura de disfarce, talvez se possa situar a melhora clínica (através do emprego de phármakons antidepressivos) de um paciente depressivo pela sua possibilidade de realizar funções para as quais ele não mais se encontrava apto, por seu retorno ao trabalho, pelo desaparecimento do seu pessimismo e de sua tristeza etc. - porém, sem que haja aquilo que ele e seus familiares reconheçam como uma recuperação do estado psíquico e comportamental anterior ao episódio depressivo/melancólico: não ocorre o restitutio ad integrum. É quando ele parece ter se tornado "uma outra pessoa".

Com efeito, na observação clínica (psiquiátrica) de pacientes melancólicos por até cerca de vinte anos, não posso deixar de distinguir um tipo peculiar de melhora em diversas dessas pessoas medicadas com variados tipos de drogas antidepressivas: ocorre geralmente uma nítida e importante melhora geral, com elevação do humor, boa disposição para as atividades costumeiras, recuperação do apetite e do sono etc. Na verdade, uns poucos itens como esses costumam compor os sintéticos questionários para a avaliação médica de tais pacientes, em sua evolução clínica. Mas quando se tem a oportunidade de acompanhar mais de perto e mais prolongadamente um paciente desses, a apreciação sobre tais casos pode ser surpreendente; é o que pude pessoalmente constatar junto a alguns pacientes melancólicos. 


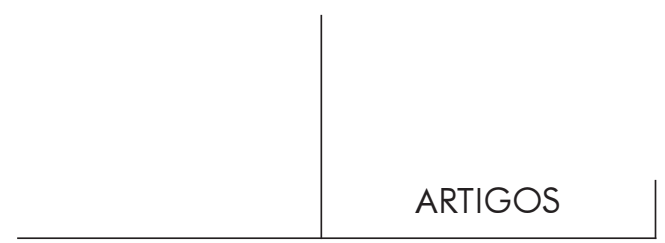

Trata-se de uma espécie de "adiamento" da destruição e do triunfo sobre o objeto perdido e identificado ao Ego, no processo psíquico melancólico - que pode ser obtido pelo sujeito a partir dos phármakons antidepressivos. O que descrevo a seguir é o resumo de um Caso Clínico, um desses que me levaram ao presente tema (que, na verdade, merece um estudo à parte deste presente texto, e é assunto de uma pesquisa psicanalítica que estou elaborando).

Lembro-me desse paciente que atendi quando internado num hospital psiquiátrico por grave crise de melancolia: contava ele, na época, 36 anos de idade; havia tentado suicídio ingerindo veneno e, quando começou a se sentr muito mal, confessou o fato à esposa que o conduziu rapidamente a um pronto socorro. Esse episódio ocorreu há cerca de quatorze anos; após a elevada e usual dosagem do antidepressivo tricíclico (Imipramina) que instaurei para combater o episódio melancólico, o paciente continuou medicado com o mesmo phármakon até há pelo menos um passado recentíssimo, de seis meses. Nesse meio tempo, a dosagem foi ligeiramente aumentada - segundo o paciente ou o médico o percebessem tendendo à melancolia - para retornar em poucos dias à baixa dose de manutenção. Tal quantidade da droga não pôde ser suspensa definitivamente, mesmo em todos esses anos (aliás, como a imensa maioria dos pacientes melancólicos que, via de regra, permanecem com o uso do mesmo antidepressivo empregado na crise aguda - mas em doses bem menores - e/ou com a tomada de drogas estabilizadoras do humor). $\mathrm{O}$ acompanhamento médico-psiquiátrico do paciente era irregular, pois ele desejava abandonar o medicamento de vez porque não queria se "sentir sempre um doente"; com isso, ele tentava condutas de outros psiquiatras, mas depois de alguns meses voltava a me procurar para prosseguir o tratamento:

- É, Dr. Rubens, já vi que não dá mesmo para ficar sem o remedinho..! dizia ele, algo envergonhado por retornar ao meu atendimento e ter obtido opiniões especializadas que teriam confirmado o acerto da minha conduta medicamentosa. O emprego de drogas estabilizadoras do humor, que poderiam tê-lo favorecido no sentido da diminuição da dosagem ou até na suspensão do uso da Imipramina, não lograram, em seu caso, boa resposta clínica.

Ele tampouco aceitou bem a indicação de atendimento psicoterápico simultâneo ao tratamento medicamentoso, abandonando dois ou três diferentes atendimentos dessa natureza sob variados pretextos situacionais: o fato de não residir em São Paulo era uma escusa muito utilizada, tanto para a descontinuidade no seu tratamento psiquiátrico comigo quanto nas psicoterapias que iniciava.

Mas o que hoje me chama mais a atenção nesse breve relato são os intensos ciúmes do paciente em relação à sua mulher: ele sempre se sentira um tanto preterido por ela, inclusive em relação aos filhos, e a mencionada tentativa de suicídio se deu quando soube que ela estava grávida (pela terceira vez). Mesmo depois de superada a crise melancólica, ele não mais retomou sua anterior e "muito cansativa" 
atividade administrativa num grande empreendimento comercial: limitou-se à atividade que também exercia numa sua grande loja. Trabalhava sempre bastante, mas julgava não poder acumular a função administrativa com a comercial:

- É, minha mulher vai ter que se conformar em não ser mais a grande dama que foi! - dizia ele com ironia, por diversas vezes, referindo-se à renúncia ao cargo administrativo. No entanto, assumiu um outro e também trabalhoso cargo no mesmo empreendimento - com a diferença que era uma função totalmente interna, sem a anterior participação social (sem que sua esposa pudesse ser a "grande dama" de antes).

- Ela agora é apenas uma mera funcionária da loja, como as outras... deixava ele escapar durante as consultas, aludindo às funções profissionais da mulher - que, a propósito, sempre trabalhara próxima a ele e que continuava a fazê-lo.

Mesmo não acusando qualquer necessidade de restrição econômica, vendeu o título do clube que a família freqüentava:

- A gente tem sempre que economizar um pouco, não é mesmo? - disse-me ele. Mas ele apenas enfatizava, em tom de brincadeira, que sua esposa não poderia mais "desfilar" de biquini na piscina do clube.

Era claro que o paciente mantivera suas ativas funções em sua loja como antes do quadro melancólico e que seu afastamento do cargo de destaque social que ocupara na outra empresa atendia suas hostilidades inconscientes contra a mulher: visava tirá-la da da posição de "grande dama" para reduzi-la à de "mera funcionária". Também o filho mais velho, que segundo ele era o "queridinho da mamãe", teve uma definição profissional bastante direcionada pelo paciente e viuse levado, pelo pai, a cursar o estudo universitário para o qual não havia ensino em sua cidade, mas em uma outra faculdade, distante mais de 200 quilômetros de casa.

Nesses quatorze anos, o paciente teve apenas um episódio de excitação tendendo à euforia, há aproximadamente seis anos, que me obrigou a suspender a dose de manutenção da Imipramina: chegava algo próximo de uma hipomania, mas não requereu medicação ou cuidados clínicos especiais. Nessa época, convoquei sua esposa para uma entrevista, visando entender o que sucedia com ele; ela me disse que ambos estavam "muito contentes":

- Ele já estava bem há muito tempo, mas fazia tantos anos que eu não o via assim: ele está como era "antes"...! - explicou ela, referindo-se ao período de antes do início do episódio melancólico.

Eu compreendi que somente após oito anos de evolução clínica o paciente chegara mais próximo de seu estado "basal" de humor: só aí então o episódio melancólico parecia finalmente terminado.

Na mesma ocasião, o paciente elevou sua mulher ao cargo de "gerente geral" de sua loja e adquiriu um sítio para a família, situado exatamente a meio caminho entre sua cidade e o local onde seu filho primogênito tinha passado a morar, forçado 


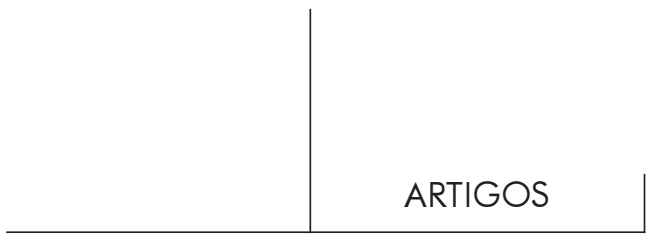

pelos estudos: o rapaz passou então a ver seus pais e irmãos com muito mais frequiência, favorecido pela proximidade geográfica e pelo caráter de lazer da nova propriedade. O paciente não se deu conta de que, após esse período quase eufórico, passara a tratar a esposa e os filhos com muito mais afabilidade e ternura. Nas consultas, ao se referir ao primogênito - antes o "queridinho da mamãe" - ele passou a falar do "garotão do pai".

A propósito, ele chegara (pela primeira vez em diversos anos) até a tentar e a parcialmente conseguir - sua volta ao antigo cargo administrativo de destaque que ocupara na empresa, antes da crise melancólica.

Até o título do clube, do qual ele se desfizera, foi readquirido; e o paciente, embora o justificasse através de uma vaga importância do contato social para os filhos crescidos, mencionava por diversas vezes que quem de fato iria gostar da iniciativa era sua mulher: na consulta.

- Ela adora tomar um sol de biquini, o que eu vou fazer? - brincava ele,

Era como se somente depois de oito anos ele tivesse conseguido concluir sua "vingança" de marido ciumento e assim pudesse, afinal, reduzir sua hostilidade contra sua esposa. Mesmo quando já não ocultava na crise melancólica clínica seu ódio e seu sadismo contra a mulher, tal carga erótica parecia ter continuado, surda e fortemente, orientada contra ela. Em "Luto e melancolia" (1917), podemos ler:

Desse modo, a carga erótica do melancólico experimenta um duplo destino. Uma parte dela retrocede até a identificação, e a outra, até a fase sádica, sob o influxo da ambivalência. ${ }^{17}$

Dessa descrição de Freud relativa ao equilíbrio econômico da melancolia, parece que apenas a força erótica ligada à identificação com o objeto odiado é modificada pela nova e poderosa pressão pulsional, irrompida a partir da reação do organismo ao phármakon antidepressivo.

Tal estado de ânimo do meu paciente perdurou por alguns meses, sendo depois necessário retornar ao uso do antidepressivo - embora apenas numa dosagem de manutenção e mais baixa do que a anteriormente mantida por diversos anos: era o suficiente para mantê-lo numa disposição geral que se pode considerar intermediária entre aquela da exaltação próxima da Hipomania e a anterior, com seus desempenhos social, familiar e profissional favoráveis, mas com um toque de amargor e ironia que nunca deixavam de, sutilmente, aparecer nas consultas. Tal amargor acinzentava todos seus planos e atitudes, sempre no sentido de buscar o que pudesse ser, indireta, mas certeiramente, humilhante e desagradável para sua esposa.

17. Sigmund Freud (1917). "La afliccion y la melancolia”. In O.C., vol. I. (Trad. de Luis LópezBallesteros y de Torres). Madrid, Biblioteca Nueva, 1968, p. 1079. 


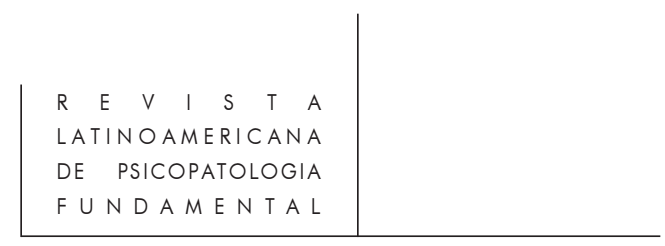

São muitos casos clínicos como o que esbocei acima que me levam a pensar nesse peculiar efeito dos phármakons antidepressivos: seu efeito de Tintura como disfarce ou simulacro. O antidepressivo, com sua superestimulação somática simultânea de vários sistemas orgânicos, deve incitar uma mobilização pulsional de energias usualmente não disponíveis pelo sujeito (creio que posso considerá-las como pulsões de autoconservação) - e que corresponderão a cargas extras a aportarem a um ego muito enfraquecido, como que dilatando-o para fazer frente ao que é percebido como uma nova e imensa ameaça externa ao sujeito. Diante de sinais de grande ameaça e urgência em diversos órgãos, o sujeito deve ser como que obrigado a adiar o prazer sádico da destruição vingativa do objeto introjetado e a mobilizar libido do superego para esses diversos setores do organismo, visando protegê-los.

Em alguns pacientes, isso deve forçar uma separação entre o objeto e o ego, diante do novo alerta a que esse deve estar pronto a acudir. A cólera do ego deverá então se manter, paralela a essa parte que retoma suas habituais funções diante da realidade, até então em grande parte suspensas.

Em outros, o objeto deverá ser destruído muito rapidamente, uma vez que o superego estará com menores exigências devido a seu esvaziamento libidinal, com a libido se direcionando aos órgãos afetados pelo phármakon. Isso deve ser o que ocorre nos pacientes que emergem contentes do estado melancólico/depressivo e aqueles que dele saem num quadro maníaco.

Outros, ainda, devem reagir a essa violentíssima mobilização somática com o ego se despregando do objeto, mas de forma a mantê-lo privilegiadamente em seu interior para destruí-lo tão logo lhe seja possível. Como Karl Abraham (1924) considera o melancólico como regredido à "última etapa oral", "com um fim sexual canibalístico" 18 , consigo imaginar um festim de canibais interrompido por um súbito e grande incêndio se espalhando pelas tendas dos selvagens: o banquete tem de ficar para depois.

Como se sabe, é quase sempre necessária a manutenção prolongada de uma dosagem mais baixa do antidepressivo, depois que o episódio melancólico cede; dentro destas minhas associações, é como se a comilança antropófaga continuasse postergada pela persistência da sentinela frente ao risco de uma faísca fazer irromper novamente o incêndio: o selvagem canibal vai ficando, então, na contingência de ir devorando sua vítima aos poucos. Parece-me terem sido estas as circunstâncias psíquicas do paciente melancólico que descrevi anteriormente.

3) Como Escritura - na duplicidade de favorecer a recordação e incitar o esquecimento, parece haver uma forte propensão atual de incitar o esquecimento;

18. Karl Abraham (1924). "Un breve estudio de la evolución de la libido, considerada a la luz de los transtornos mentales" (Trad. de Daniel Ricardo Wagner). In Psicoanálisis clínico, Buenos Aires, Hormé, 1980, pp. 365-381. 


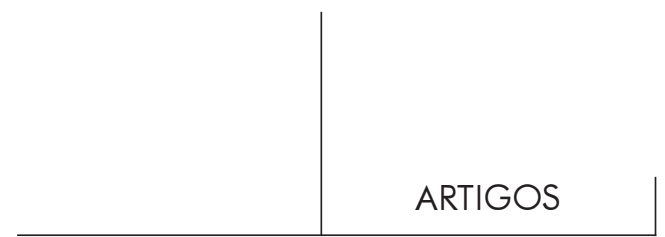

não propriamente pela confiança no que está escrito, pois muitas vezes a descrição escrita do phármakon não passa pelo filtro da confiança, mas pela exigência contemporânea de o paciente comportar-se como quem tem uma saúde excelente. Em nossa era obsessiva, o ideal do ego fica, coletivamente, ocupado pela imagem de um homem jovem, musculoso, belo e altamente produtivo - com uma saúde permanente e sem limites garantida pelo mesmo sistema de produtividade que dele exige essas características utilitárias; assim, as virtudes dos medicamentos descritas como benéficas (o efeito de droga como remédio) são percebidas pelo paciente mais como uma ordem-do-dia do que um aceno com potencial de cura.

A bula do medicamento, assim como as frases da sua embalagem, são a própria concretização gráfica visível do efeito-Escritura, como um rígido cânone a ser obedecido; até há uns trinta anos (em nosso meio), a bula continha informações consideradas pertinentes a uma situação de emergência, para o caso da ausência do médico que cuidava do paciente, ou para uso desse próprio médico, que não poderia conhecer todas as possíveis direções que a droga eventualmente seguiria. Os doentes costumavam dizer que "não entendiam nada" do que ali estava impresso; que as letras eram muito pequenas etc., sempre no sentido de expressar um repúdio por seu conteúdo escrito. Tampouco mostravam essa preocupação atual com as mudanças na apresentação da caixa ou do tubo do medicamento: o médico "sabia" do remédio, não havia motivos para cogitações de suspeita.

Hoje, quando o paciente quer exprimir sua confiança no médico, ou uma grata satisfação com os tratamentos que esse profissional costuma lhe ministrar, ele muitas vezes o faz com um comentário que revela uma exceção nos atuais hábitos frente a medicamentos:

- Doutor, eu nem quis ler a bula do seu remédio! - diz ele, em tom confidencial e carinhoso.

O phármakon, para pacientes como esse, se desprega da abóbada da saúde ideológica e retorna para a imagem do seu médico de confiança: o efeito de escritura readquire movimento e volta a ser escrito a quatro mãos.

O efeito de escritura de incitar o esquecimento é então plenamente dominante nos pacientes para os quais a bula e a embalagem estão acima do médico que os atendeu, ou que até nem recorreram a qualquer médico para obter um tratamento; o que aqui esse doente quer esquecer inclui a experiência de que ele próprio já fez uso de drogas muito semelhantes a essa em suas promessas, mas cujos efeitos não lhe foram satisfatórios. Inclui, também, esquecer os fatores de sua história pessoal que ele intui e pressente que estão agindo fortemente na sua moléstia atual - falha de memória a favor da droga do momento, droga que encerra o subentendido obrigatório de que uma nova e mais poderosa substância irá logo surgir enquanto ele tolera os efeitos previamente insuficientes dessa que ele está agora adquirindo na drugstore. 


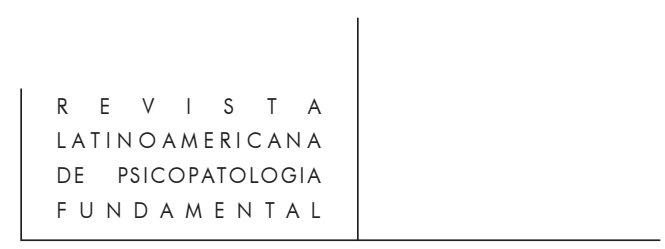

Um paciente como esse (como tantos) aceita as indicações terapêuticas da droga, sua posologia e demais itens da bula como a parte escrita de seu ritual de adaptação às exigências da ideologia da produtividade; entre essas, além da de se curar o mais rapidamente possível, também figuram os concomitantes desse tipo de saúde visada pela cura: o apresentar-se com aparência saudável aos colegas e superiores (pelo efeito de Tintura); o aprimorar-se continuamente na técnica de sua profissão; o dispor cada vez de mais dinheiro e mais conforto e - acima de tudo a tarefa de compor essas virtudes numa finalidade utilitarista de produção pragmática.

A própria data de validade marcada na embalagem, sempre verificada pelo paciente de nossos dias, encerra uma fixa e longa margem de duração do produto; se racionalmente ela assim deveria conferir ao medicamento uma força de respeito e seriedade da sua comercialização, por outro lado (certamente o mais forte), a extensão da validade indica que os efeitos da droga não se destinam propriamente ao paciente que está lendo a escritura da embalagem, pois costuma ultrapassar em muito o tempo de que ele poderá ter necessidade de utilizá-la. O paciente percebe, mesmo sem o desejar, que ele simplesmente passou a fazer parte de uma vastíssima fila de pessoas anônimas que também precisam reverenciar esse medicamento, tanto antes como depois dele tê-lo feito.

Daí se compreender com facilidade que muitos pacientes, tendendo mais a 30 uma busca da escritura em seu efeito de favorecer a recordação, tenham preferência por phármakons em "fórmulas" prescritas diretamente por seus médicos e por remédios em geral elaborados em drogarias de manipulação - onde ele ao menos pode ver o local onde seu medicamento é feito e o rosto das pessoas que ali participam desse processo. Drogas vindas do Oriente, ervas especiais, produtos homeopáticos e outros - independentemente de quaisquer eficácias consideradas como terapêuticas e farmacológicas - com certeza também podem trazer essa característica de escritura de serem "personalizadas", como um fortíssimo elemento de atração para as pessoas com essa disposição de espírito para a recordação.

Pierre Fédida (1998), comentando o mesmo referido livro de Derrida, assinala que pode ocorrer de a própria pessoa do médico vir a se qualificar

... como pharmakon pelo excesso de sua potência sobre o doente e produzirá um tipo de logro acompanhado no doente de um desvio ou esquecimento de si. A verdadeira ciência é a anamnese no sentido em que a questão que é dirigida ao doente traz esta lembrança que, em si, conduz a fala ao falar. ${ }^{19}$

Esse médico que pode assim se qualificar como phármakon (aqui, na acepção do logro ou do disfarce) para o seu doente, com essa desmesura do excesso

19. Pierre Fédida. "A fala e o pharmakon" (Trad. de Monica Seincman). Revista Latinoamericana de Psicopatologia Fundamental, vol. I, no 1, 1998, pp. 29-45. 


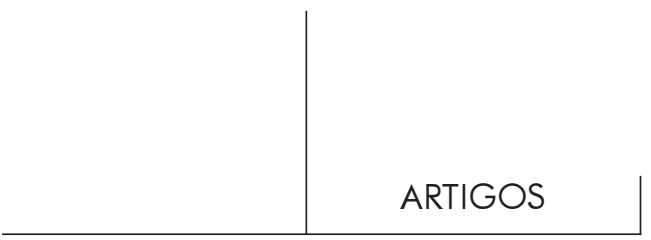

podendo assim produzir um desvio ou esquecimento de si no paciente, só poderia ser o médico livre de que Platão nos fala em "As leis"; pois o outro, o médico escravo, não atingiria essas altitudes psíquicas nos seus pacientes. O efeito de phármakon da sua pessoa não poderia senão desempenhar o logro da desmesura pela falta, podendo eventualmente um excesso no psiquismo do doente ser constituído pela imagem de seu dono - imagem que é imprescindível para que houvesse alguma receptividade pelos pacientes que recorriam aos préstimos de um médico escravo (mesmo se procedendo dessa forma pelo simples fato de não terem acesso a outro tipo de médico).

Mas tal possibilidade de efeito-veneno (denominado nos dias de hoje como efeito colateral ou mesmo como overdose) também inclui aquela de remédio, de medicamento benéfico - este também somente através do médico livre.

4) Como Objeto Numinoso - muitos dos médicos contemporâneos, desafortunadamente, já não conseguem desempenhar essa sua ancestral função hipocrática que lhes permitiriam disparar a centelha do efeito Numinoso dos phármakons que prescrevem a seus pacientes; suas imagens ficam muitas vezes situadas numa posição psíquica comparável àquela certamente ocupada pelos médicos escravos gregos, desprovidos que estão da liberdade e da atitude platonicamente dialética, imprescindíveis para que se possa irradiar a força numinosa que remetere ao "sagrado" dos mistérios atribuídos à Medicina. A função expiatória, então decorrente das forças inconscientes do enfermo ao mobilizarem seus sentimentos de culpa - ligados à doença para a qual buscam tratamento - muitas vezes também já não pode ser cumprida como antes: pela sujeição aos rigores do diagnóstico, do tratamento e da evolução clínica do paciente junto ao facultativo. É que o doente, muitas vezes, praticamente já perdeu o seu médico.

Não é exato pensarmos que os médicos, sejam psiquiatras ou de outras especialidades, fiquem embevecidos com os novos phármakons, inclusive com os mais novos antidepressivos; segundo percebo, a maioria desses profissionais, no mais das vezes, não encontra outra saída senão prescrevê-los. Diante dessa "robotização da medicina", o próprio Presidente do Conselho Regional de Medicina do Estado de São Paulo (Dr. Pedro Paulo Roque Monteleone) externou, num artigo, seu desalento frente à "moderna tecnologia" e seus altíssimos custos: seu receio de que esses dois fatores sejam controladores da liberdade do médico e de que, assim,

...tudo, daqui para frente, limitar-se-á a protocolos rígidos e drásticos, impostos à classe médica. Pior. Serão impostos desde os bancos universitários: o aluno de Medicina aprenderá de acordo com tais regras. ${ }^{20}$ (grifos meus)

20. Pedro Paulo Roque Monteleone. "Robotização da medicina?", Jornal do CREMESP, Ano XVII, no 127, março/1998, p. 10. 


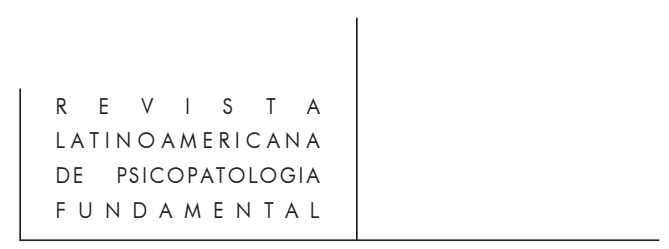

Nos textos hipocráticos, encontramos claro o reconhecimento do elemento numinoso através da alusão à existência de forças divinas; embora algumas vezes se pense que Hipócrates concebeu uma Medicina "atéia" - com ausência de forças superiores às do racionalismo humano ou sem forças superiores às dos movimentos compreensíveis da mecânica da Natureza - isso é equivocado. As relações dessa Medicina com "os deuses" simplesmente não é direta, ou seja, a saúde e a doença não ficam à simples mercê da boa ou má vontade dos desígnios divinos, cujo favor imponderável se tentaria obter e cuja cólera igualmente imprevisível se tentaria abrandar.

Esse temor reverencial e totalizante às divindades é a tônica central da medicina dominante na Grécia de Hipócrates, aquela dos mais antigos e tradicionais "sacerdotes-curadores" dos templos dedicados ao deus Asclépio - os Asclepéia (como se sabe, o Asclépio dos gregos, deus da Medicina, é o mesmo Esculápio dos romanos) - os poderosos rivais e concorrentes da então nascente Medicina hipocrática. ${ }^{21}$

Há um respeito à idéia de forças divinas nos textos do Corpus Hippocraticum, sem a devoção religiosa dos crentes, mas com o respeito devido a potências inapreensíveis atuando na natureza, pelos próprios métodos naturais, como motor de um todo universal natural (o natural da filosofia jônica da natureza, que mencionamos anteriormente).

No texto "Sobre a doença sagrada", por exemplo, comumente se pretende reconhecer uma destituição do caráter sagrado da epilepsia - que estaria então situada, pelo médico hipocrático, de maneira idêntica à mais usualmente concebida hoje em dia: uma doença com localização cerebral, oriunda de diversas razões materiais detectáveis apenas nos próprios tecidos do cérebro, podendo ser considerada como fruto de causas invisíveis ou impalpáveis apenas na ignorância de pessoas supersticiosas. Mas se lermos com atenção as páginas da obra, veremos que a explicação hipocrática da moléstia pela physiología aponta numa direção que absolutamente não exclui o elemento misterioso ou indecifrável dessa ou de quaisquer outras doenças, mas que tão-somente visa defender o doente da má-fé ou da inépcia de curandeiros:

Penso que os primeiros a sacralizarem essa doença foram gente como os atuais magos, purificadores, charlatães e enganadores que se dão ares de muito piedosos e de terem grande saber. Eles, de fato, tomaram o divino como abrigo e escudo de sua incapacidade, por não disporem do remédio de que pudessem lançar mão; e para que não ficasse evidente que nada sabiam, estimaram essa doença como sagrada. ${ }^{22}$

21. Hernâni Donato. Os cientistas. São Paulo, Cultrix, 1961, pp. 27-39.

22. Hipócrates. "Sobre la enfermedad sagrada" (Trad. de Carlos García Gual). In Tratados Hipocráticos, op. cit., p. 400. 


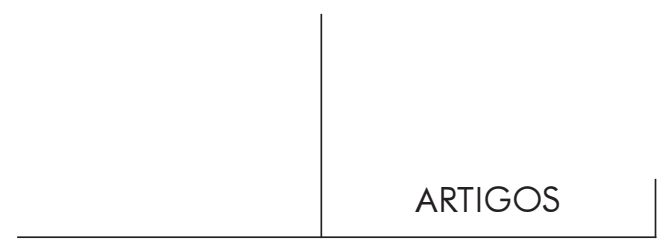

É como se o sagrado ou numinoso estivesse reservado para mais elevadas ou complexas manifestações da sensibilidade humana. O mesmo texto hipocrático comenta, sobre esses então falsos curandeiros:

Com seu palavrório e maquinações, fingem saber algo superior e enganam as pessoas, recomendando-lhes purificações e expiações e o elemento de sua fala é a invocação do divino e do demoníaco. Parecem-me não construirem seus discursos em torno da piedade, como crêem eles, mas sim em torno da impiedade e da crença de que não existem os deuses, e seu sentido do piedoso e do divino é ímpio e blasfemo. ${ }^{23}$

Essa possibilidade de remeter ao mágico, numa função expiatória, realiza-se em nossos dias na magia atribuída ao ilimitado dos recursos científicos, tal como ela é estimulada pelo credo da produtividade. Como uma nova religião, inclusive como parte do caráter obsessivo de nossos dias, a ciência assim promovida como avalisadora de uma saúde eterna vem ficando oficialmente incumbida dos milagres necessários. A própria medicina, por seu turno, vem sendo reduzida a uma das etapas mecanizadas finais na fabricação dessas maravilhas: a magia centrada na figura idealizada do médico vai sendo aceleradamente substituída por essa outra, anônima e multiforme magia universal.

A função expiatória coletiva deveria se consubstanciar no ritual de compra do phármakon e na subordinação a ele - visível no enfermo como a intenção consciente de utilizá-lo como um sacrifício necessário pela saúde pessoal, sacrifício propiciatório de graças por uma subordinação à todo-poderosa saúde universal.

No entanto, essa substituição do ritual grego para as ocasiões de algum desastre na cidade de Atenas - expulsando da cidade dois indivíduos (os pharmakoi) "carregados" pelos males e fustigando-os brutalmente nos genitais ${ }^{24}$ - não poderia se limitar a um simples pedido pelo phármakon na drogaria; tampouco a expiação poderia ser resumida ao tão simples pagamento pela compra, depositado nas mãos "impuras" do funcionário do caixa. Até o gesto de solicitar o medicamento foi muitas vezes abolido na drugstore, com o acesso direto do comprador às prateleiras dos produtos: tudo feito sem a mínima solenização, tudo dessacralizado e vazio de qualquer possibilidade de algum efeito Numinoso.

Isso certamente tem um contraste ainda maior com o passado recente num país como o Brasil, no qual as farmácias fizeram as vezes dos raros hospitais disponíveis e os farmacêuticos desempenharam o importantíssimo papel de substitutos dos então escassos médicos existentes. Mesmo na cidade de São Paulo,

23. Idem, p. 402.

24. Jorge J. Saurí. Op. cit., p. 21. 


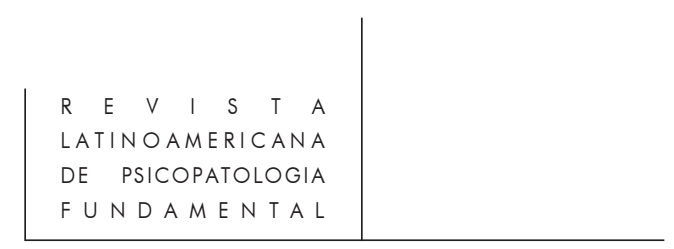

até pelo menos os anos de 1930, as farmácias tinham o seu maior volume de medicamentos nas formulações feitas pelos médicos; e nelas, do lado de fora do balcão, sentavam-se para conversar com o dono da farmácia os seus freqüentadores habituais do final do dia: um funcionário público, um fazendeiro, um professor da Faculdade de Direito, um comerciante. ${ }^{25}$ Era um clima de credibilidade para o cliente, diante dessa presença de pessoas procedentes de setores respeitáveis da coletividade.

Para que a tão profana aquisição do phármakon adequado na drugstore possa ter uma função psíquica expiatória, para que se torne uma verdadeira romaria pela cura, para que tenha a força de uma prece pela saúde, é preciso que o banal movimento físico da marcha rumo ao estabelecimento da drogaria se carregue também de associações relativas aos temores de internações hospitalares, de tratamentos incômodos e arriscados, de exames complementares dispendiosos, imagens que vêem impregnadas da noção de uma espera angustiada pelos resultados sempre imprevisíveis de todos esses procedimentos. O reles pagamento do produto a um funcionário sonolento, por seu turno, só pode ser inconscientemente valorizado pelo freguês se ele o tomar como uma extensão do já "sagrado" pagamento mensal do plano de saúde.

Quando, ao final do seu livro, Derridaa ${ }^{26}$ imagina Platão saindo da farmácia com um phármakon na mão e põe o filósofo procurando distinguir entre duas repetições para separar a verdadeira da falsa, os sons se esbatem, se contradizem, se rearticulam e a própria filosofia começa então a medrar - no fugidio dos contrários e dos semelhantes, na formação de sentidos, nos vapores daquele phármakon.

Na melancólica drugstore de hoje, o Divino Platão certamente teria que se restringir a sair atônito da loja, tendo nas mãos um saco plástico repleto de produtos: shampoos, medicamentos, biscoitos dietéticos etc. Em meio aos demais apressados fregueses, ele talvez remexesse a sacola, tentando derivar filosofia dos mistérios do phármakon: mas apenas encontraria ali um product, em sua colorida caixa de medicamento, que ainda consegue guardar as propriedades do phármakon hipocrático somente através de permanentes malabarismos de psicologia de massas, de extrapolações da tecnologia científica, do sufoco e da estreiteza de tantos atendimentos médicos e, sobretudo, à custa das duríssimas penas impostas aos atuais clientes: nós, os fregueses sem rosto dessa Drugstore que, um dia, já foi a Farmácia de Platão.

25. Jorge Americano. São Paulo naquele tempo: 1895-1915. São Paulo, Saraiva, 1957, pp. 493495.

26. Jacques Derrida. A farmácia de Platão (Trad. de Rogério da Costa). São Paulo, Iluminuras, 1991, p. 123. 


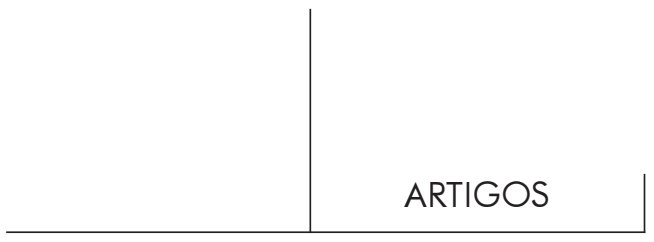

Resumos

De La Farmacia de Platón - el libro de Jacques Derrida - la admiración del filósofo Griego para la incipiente medicina hipocrática es remontada por el autor en los textos platónicos. Esta medicina armonizó al método dialético de Platón en oposición a la estrechez del método sofista mejor satisfizo la medicina pre-hipocratica de los sanadores charlatanes. El pharmakon del Hipocrates, com sus propiedades primitivas e aún actuales de d roga, de Tinte, de Escritura y de Objeto Numinoso, se alcanza.

La Drugstore actual, que vino a usurpar el espacio tradicional ocupado por la farmacia, mantiene el pharmakon como a tal. Debido a los esfuerzos de la propaganda maciza, de las exorbitancias de la investigación científica y de la precariedad de la mayoría de las asistencias médicas de nuestros tiempos el pharmakon no está reducido él a la categoría inerte de un simple product.

Hay, también en psicofarmacologia muchas modificaciones (patoplasticas) generadas por las mutilaciones contemporaneas sufridas por el pharmakon. El del autor enfatiza, entre ellos, que el pharmakon de los antidepressivos, en el re-equilibrio pulsional que ellos favorecen y a pesar de la aparente mejora en el cuadro clínico, puede llevar, en el melancólico, a un tipo de "aplazamiento" de la destrucción y del triunfo encima del objeto perdido y no parece tener cualquier influencia en la fuerza sádica destructiva del sujeto.

Palabras-llave: Psicopatología, psiquiatría, psicofarmacos, pharmakon.

Nous recherchons dans les propres textes platoniciens, à partir du livre La pharmacie de Platon de Jacques Derrida, les traces de l'admiration du philosophe Grec pour la medecine d'Hypocrate alors à son début. Cette medecine s'harmonisait avec la mèthode dialectique de Platon et s'opposait à l'étroitesse de la méthode sophiste, celle ci plus en relation avec la medecine pre-Hypocrate des charlatans soigneurs.

Nous arrivons au pharmakon d'Hypocrate, avec ses caractéristiques primitives e actuelles de Drogue, Teinture, Écriture et d'Objet Nomineux. Dans l'actuel Drugstore, qui vint à usurper l'espace traditionnellement occupé par la Pharmacie, le pharmakon se mantient en tant que tel et ne se réduit pas à la catégorie inerte d'un simple product le tout dî aux efforts de publicité massifs, aux extravagances de la recherche scientifique et à la précarité de la plupart des consultations médicales actuelles.

Nombreuses sont en Psychopharmacologie, les modifications (pathoplastiques) gérées par les mutilations contemporaines qu'a souffet le pharmakon; l'Auteur met en particulier en relief celles que les pharmakons antidépressifs peuvent provoquer, touchant au réequilibrage pulsionnel et favorisant à peine une espèce de retard de la destruction et du triomphe sur l'objet perdu chez le mélancolique, ne semblant pas avoir d'influence, malgré une apparente amélioration du cadre clinique, sur la force sadique destructive du sujet.

Mots-clef: Psychopathologie, psychiatrie, psychopharmacologie, pharmakon. 


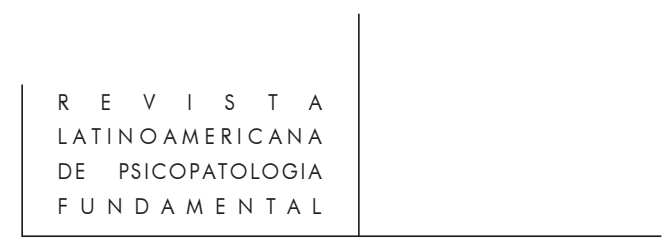

From the Pharmacy of Plato - the book of Jacques Derrida - the Greek philosopher's admiration for the incipient hipocratical medicine of that times is traced by the author in the platonic texts. This medicine harmonized to Plato's dialetic method in opposition to the narrowness of the sofist method that better suited the prehipocratical medicine of the charlatan healers.

The hipocratical pharmakon, with its primitive and still current properties of Drug, of Tincture, of Script and of Numinous Object, is reached. The current Drugstore, that came to usurp the traditional space occupied by the pharmacy, maintains the pharmakon as such. Due to the efforts of the massive propaganda, of the exorbitances of the scientific research and of the precariousness of most of the medical attendances of our times the pharmakon is not reduced to the inert category of a simple product.

There are, also in Psychofarmacology, many (pathoplastic) modifications generated by the contemporary mutilations suffered by the pharmakon. The Author emphazises that the antidepressive pharmakons favor the pulsional re-balance. In spite of the apparent improvement in the clinical picture, they may lead, in the melancholic, to a type of "postponement" of the destruction and of the triumph over the lost object. However, in this case, they don't seem to have any influence in the self's destructive sadistic force.

Key words: Psychopathology, psychiatry, psychopharmaco, pharmakon. 